\title{
AGEL트
}

\section{Adensamento urbano e usos sociais de áreas verdes públicas da cidade de Garanhuns-PE}

\author{
Urban densification and social uses of public green areas of \\ the city of Garanhuns-PE
}

\section{Densificación urbana y usos sociales de áreas verdes públicas de la ciudad de Garanhuns-PE}

\author{
Ana Maria Severo Chaves \\ Universidade Federal de Sergipe \\ anamschaves05@gmail.com \\ Rosemeri Melo e Souza \\ Universidade Federal de Sergipe \\ rome@ufs.br
}

\begin{abstract}
Resumo
As áreas verdes públicas urbanas são espaços bem arborizados e representam ícones de bem-estar e de qualidade ambiental do meio citadino, devido aos diversos benefícios gerados pela vegetação, além proporcionarem dinamicidade e beleza ao espaço urbano. As áreas verdes públicas (AVPs) também correspondem a espaços livres, de usos sociais acessíveis a toda população e lugar de lazer. Assim, a presente pesquisa teve por objetivo analisar o adensamento urbano em que áreas verdes públicas da cidade de Garanhuns-PE estão inseridas, bem como, quais são os usos sociais desenvolvidos nas áreas estudadas. Para tal, a pesquisa é baseada na análise sistêmica da paisagem com suporte de trabalho de campo e de sistemas de informações geográficas (SIG) para a confecção de mapeamentos. Como principais resultados, observou-se que o adensamento urbano se refere as áreas de caráter comercial e residencial com pouca verticalização. Já os seus usos são diversificados quando a AVP dispõem de algum tipo de equipamento de uso social, sendo os parques urbanos os espaços com melhores condições de usos.
\end{abstract}

Palavras-chave: Lazer. Espaços Livres. Fitogeografia. Paisagem.

\section{Abstract}

Public urban green areas are well-wooded spaces and represent icons of well-being and environmental quality of the city environment, due to the diverse benefits 
generated by the vegetation, while also providing dynamicity and beauty to the urban space. Public green areas (PGAs) also correspond to free spaces, aimed at accessible social uses by the entire population, as well as leisure places. Thus, the present research had as aim the analysis of the urban density in which public green areas of the city of Garanhuns-PE are inserted, as well as what social uses are developed in the studied areas. To this end, this research is based on the systemic analysis of the landscape with the support of fieldwork and geographic information systems (GIS) for mapping creation. The main results indicate that the urban densification refers to areas of commercial and residential character, with little verticalization. Their uses become diversified when the PGA has some kind of equipment destined for social use, with urban parks being the spaces presenting the best conditions of use.

Keywords: Recreation. Free spaces. Phytogeography. Landscape.

\begin{abstract}
Resumen
Las áreas verdes públicas urbanas son espacios muy arbolados y representan íconos de bienestar y de calidad ambiental de la ciudad, debido a los diversos beneficios generados por la vegetación, además de proporcionar dinámica y belleza al espacio urbano. Las áreas verdes públicas (AVPs) también corresponden a espacios libres, de usos sociales accesibles a toda la población y lugar de esparcimiento. Así, la presente investigación tuvo por objetivo analizar la densificación urbana en que las áreas verdes públicas de la ciudad de Garanhuns-PE están insertadas, así como también, cuales son los usos sociales desarrollados en las áreas estudiadas. Para tal, la investigación está basada en el análisis sistémico del paisaje con soporte de trabajo de campo y de sistemas de informaciones geográficas (SIG) para la confección de mapeamientos. Como principales resultados, se observó que la densificación urbana se refiere a las áreas de carácter comercial y residencial con poca verticalización. Sus usos ya son diversificados cuando las AVP disponen de algún tipo de equipo de uso social, siendo los parques urbanos los espacios con mejores condiciones de usos.
\end{abstract}

Palabras clave: Ocio. Espacios Libres. Fitogeografía. Paisaje.

\title{
Introdução
}

Na construção da cidade, o homem transforma o espaço, altera o meio ambiente e contribui e/ou intensifica os processos de deterioração dos elementos naturais mais sensíveis às perturbações antrópicas, tais como a remoção da vegetação, cortes em encostas, poluição de rios e do ar.

Gois, Figueiredo e Melo e Souza (2014, p.24), comunicam que na atualidade a degradação das áreas verdes é um dos grandes problemas ambientais presentes nas cidades, por se tratar de um ambiente no qual prevalece à natureza artificial e tecnificada, "tendo em vista o contributo da componente arbórea para a qualidade de vida neste recinto, seja pela amenização do clima, proporcionando um melhor conforto térmico, ou até criando cenários de contemplação e lazer".

A presença da vegetação, principalmente de espécies arbóreas nos espaços livres de canteiros, praças e parques é essencial para o adequado desenvolvimento do 
meio citadino, tendo como principais benefícios, advindos de tal presença, o ambiental, o estético e o social.

As áreas verdes públicas (AVPs), atualmente, correspondem a espaços livres bem arborizados que contemplam a cidade com a presença de elementos naturais, bem como proporcionam um ambiente de uso público para o desenvolvimento de atividades recreativas, pois sabe-se que são poucos os espaços urbanos que possibilitam lazer gratuito a população de forma geral.

De acordo com o Ministério do Meio Ambiente (BRASIL, 2014), as áreas verdes urbanas são conceituadas como conjunto de áreas intraurbanas compostas por cobertura vegetal, arbórea, arbustiva e/ou rasteira, nativa e/ou introduzida, que contribuem de modo significativo para a qualidade de vida e o equilíbrio ambiental das cidades. Essas estão presentes em espaços públicos ou particulares, como área de preservação permanente, jardins, praças, parques e em terrenos entre outros espaços livres.

A resolução CONAMA n 369/2006 esclarece que áreas verdes públicas correspondem a espaços de domínio público, livres de impermeabilização, dotados de vegetação, desempenhando as funções ecológica, paisagística e recreativa, bem como, proporcionando a melhoria da qualidade estética, funcional e ambiental da cidade.

Assim, diante de tal panorama, o texto teve como objetivo analisar o adensamento urbano em que áreas verdes públicas da cidade de Garanhuns-PE estão inseridas, bem como, quais são os usos sociais desenvolvidos nas áreas estudadas.

\section{Contextualização teórica do estudo}

Nucci (2008) nos traz em seu livro Qualidade Ambiental e Adensamento Urbano, que adensar é intensificar o uso e ocupação do solo como uma proposta de planejamento, verticalizando as cidades e, assim, evitando a expansão destas para as periferias ou locais inadequados para construção de moradias.

A cidade necessita de planejamento e alternativas positivas para a construção de um ambiente com mais qualidade, que evitem o crescimento e ocupação de locais ociosos e perigosos para a habitação (NUCCI, 2008). Porém, adensar nem sempre vai apresentar a decisão mais acertada, uma vez que, quando esse processo não tem controle, são criadas barreiras que dificultam a circulação do ar no interior da cidade e contribuem para a intensificação e manutenção de ilhas de calor.

Assim, ao invés de se melhorar a qualidade ambiental das cidades para os cidadãos, com moradias em lugares seguros, acaba-se contribuindo para um ambiente quente, poluído, oposto ao bem-estar da população residente.

Nesse contexto, as áreas verdes são elementos que melhoram o quadro ambiental da cidade, devido aos diversos benefícios proporcionados, além de serem local 
de usos sociais múltiplos para o lazer, sejam esses em atividades ativas ou passivas, desenvolvido pela população urbana.

Segundo Nucci (2008), os governantes têm introduzido no planejamento urbano a preocupação com o lazer, que tem avançando juntamente com as mudanças econômicas e sociais ao longo da segunda metade do século XIX e durante o decurso do século XX, fato verificado por causa da intensa aglomeração humana nas cidades e as lutas sociais pelos direitos humanos.

Conforme está disposto no Estatuto da cidade (Lei no 10.257/2001), o lazer é direito social. Por essa razão, faz-se necessária uma política urbana que ordene o pleno desenvolvimento das funções sociais da propriedade urbana, de modo a garantir "direito a cidades sustentáveis, entendido como o direito à terra urbana, à moradia, ao saneamento ambiental, à infraestrutura urbana, ao transporte e aos serviços públicos, ao trabalho e ao lazer, para as presentes e futuras gerações" (BRASIL, 2001, p.15).

Espaços para o lazer urbano não podem faltar nas cidades, os mesmos devem ser de acesso livre a todos, bem como, contemplar todas as áreas urbanas, sejam essas centrais ou periféricas. Não se trata de benfeitorias urbanas, e sim do direito de vida de cada indivíduo, moradia, trabalho, saúde, educação e lazer.

A cidade não pode se apresentar apenas como um ambiente de negócio. Ela é, sobretudo, um ambiente de vida humana sobre a qual se projetam valores espirituais perenes ao lado do traçado urbano, das fachadas arquitetônicas e do mobiliário urbano. Diante desse cenário, as áreas verdes são componentes fundamentais da paisagem urbana, no cenário da ordenação urbanística com função social (ARFILLE, 2004). define como:

Outra lei que dá destaque a área verde urbana é o Código Florestal. essa a

Espaços públicos ou privados, com predomínio de vegetação, preferencialmente nativa, natural ou recuperada, previsto pelo Plano Diretor e nas Leis de Zoneamento Urbano e Uso do Solo do município, indisponíveis para construção de moradias, destinados aos propósitos de recreação, lazer, melhoria da qualidade ambiental urbana, proteção dos recursos hídricos, manutenção ou melhoria paisagística, proteção de bens e manifestações culturais (BRASIL, 2012, p.5).

Não só na legislação brasileira está posta a importância das áreas verdes urbanas como local de lazer, haja vista que vários autores as definem como espaços de usos sociais. Bargos (2010), por exemplo, entende como função social de áreas verdes aquelas de usos públicos, dotadas de serviços capazes de garantir o bem-estar psicológico, social, estético, educativo, recreativo e de lazer a população.

Pedrosa e Gaia (2013) definem a função das áreas verdes como conjunto de elementos e atividades inter-relacionadas em um espaço com a capacidade de gerar 
benefícios sociais e ecológicos que podem garantir a qualidade ambiental e o bem-estar de uma comunidade.

Santana e Elali (2015), citando Yurgel (1983), apontam a necessidade de se entender o lazer e a recreação como atividades essenciais ao bem-estar e ao desenvolvimento humano, compreendendo o espaço público é o local privilegiado para essa atividade, cabendo a política urbana elevar o seu planejamento a esse cumprimento.

Embora alguns autores optem por distinguir lazer e recreação, no presente texto não se tem essa finalidade, pois independente da definição, aqui está se analisando os usos sociais que ocorrem em áreas verdes públicas de Garanhuns.

Nesse sentido, tais terminologias (a recreação e lazer) incidem na utilização do tempo que sobra do horário de trabalho ou do cumprimento das obrigações habituais para a realização de atividades prazerosas necessárias ao descanso diário e semanal, em que as pessoas libertam-se dos estresses e tensões gerados pela vida (ARFILLE, 2004). Essas atividades ocorrem de forma individual ou em grupo, onde cada indivíduo entregase ao divertimento ou distração por meio de diferentes práticas.

As áreas verdes, típicas ou mistas, desempenham maiores possibilidades de usos sociais. No caso, quando a área verde é de natureza mista, ela possibilita o uso público diversificado e pode conter a implantação de equipamentos para o desenvolvimento de várias atividades. As de natureza típica são áreas verdes onde a preservação ecológica predomina e é permitido o mínimo de interferência (ARFILLE, 2004).

Gomes et al. (2012) colocam em questão a importância das praças e parques no contexto do espaço urbano, por serem áreas específicas nas cidades que remetem à conservação da natureza, e que por isso pressupõem o contato do homem com a natureza, como destinados a diferentes atividades de lazer, ativo ou contemplativo (passivo).

O lazer ativo em AVPs permite que seus frequentadores realizem exercícios como correr, desenvolver alguma prática esportiva, levar crianças para brincarem, andar de bicicleta, patins ou skate, atividades que colocam o corpo em movimento. Já o lazer passivo são atividades de repouso e descanso do corpo, não exigindo muito esforço em sua realização, como, contemplação da paisagem, caminhar, sentar em um banco para ler um livro, conversar com amigos, refletir sobre a vida ou namorar.

\section{Cenário de estudo: áreas verdes públicas da cidade de Garanhuns-PE}

Garanhuns localiza-se no Agreste Meridional do Estado de Pernambuco, nas coordenadas geográficas de $08^{\circ} 53^{\prime}$ ' $25^{\prime}$ ' de latitude sul e $36^{\circ} 29^{\prime} 34^{\prime \prime}$ de longitude oeste. Faz limite ao norte com Capoeira e Jucati, a sul com Terezinha, Lagoa do Ouro, Brejão e 
Correntes, a leste com São João e Palmeirina, e a oeste com Caetés, Saloá, Paranatama, Brejão e Terezinha (MASCARENHAS et al., 2005) (Figura 01).

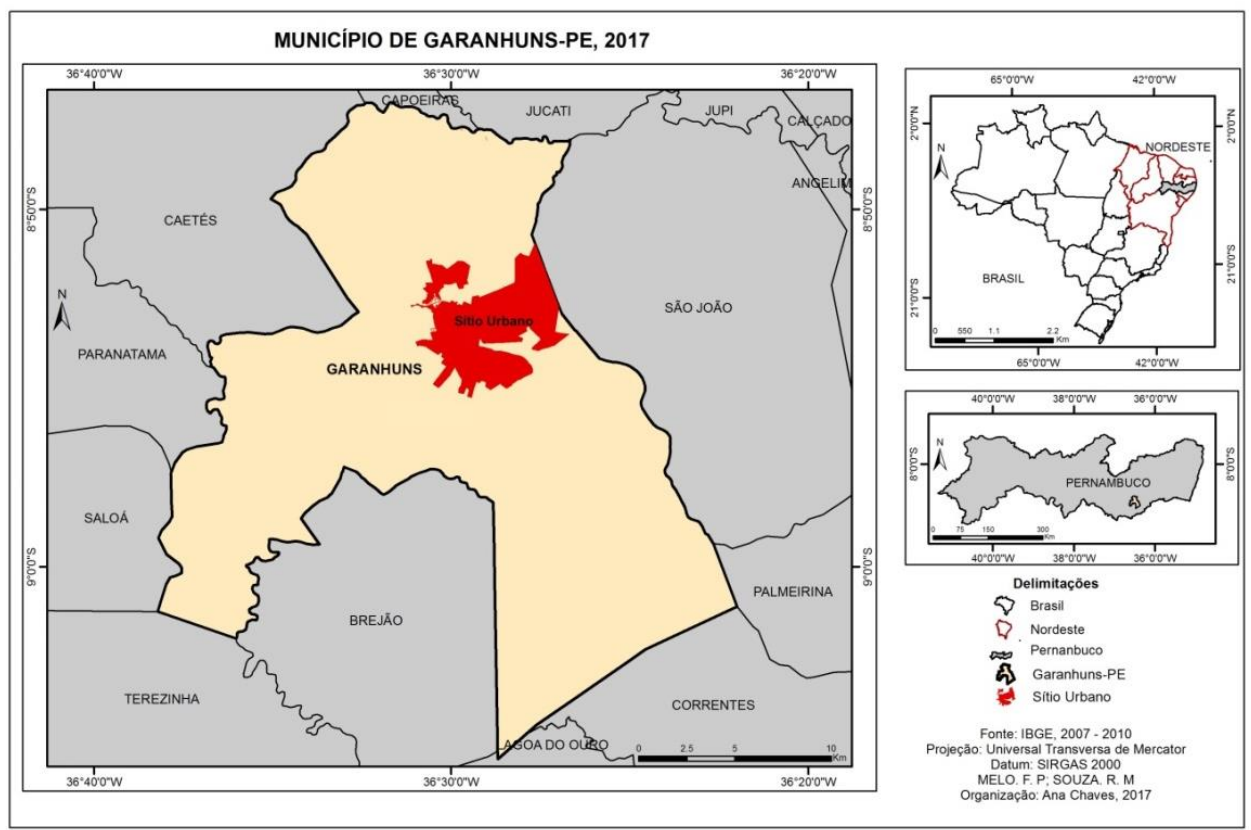

Figura 01: Localização do município de Garanhuns-PE.

Fonte: Elaborado pelas autoras (2017).

A população, de acordo com o senso de 2010, é de 129.408 habitantes. Desses, 115.356 residem no sítio urbano (IBGE, 2010), o que reflete em um elevado adensamento urbano, no qual ocorre a ocupação em áreas inadequadas para habitação, como encostas e fundos de vales.

Do ponto de vista turístico e cultural, a cidade se destaca por realizar festivais, tais como o Festival de Inverno, Festival de Jazz e o Festival Dominguinhos. Além de ser conhecida como a "Cidade das Flores", devido à presença constante de vegetação nas principais áreas de acesso à cidade, em parques, praças e canteiros centrais.

As principais áreas verdes públicas da cidade estudada correspondem a quinze espaços que variam na forma, tamanho, extensão e altitude no traçado do arruamento e da morfologia do sítio urbano de Garanhuns. A maioria contempla o formato de figuras geométricas como retângulos e triângulos, inseridos nos formatos e encaixes dos arruamentos (figura 02). 


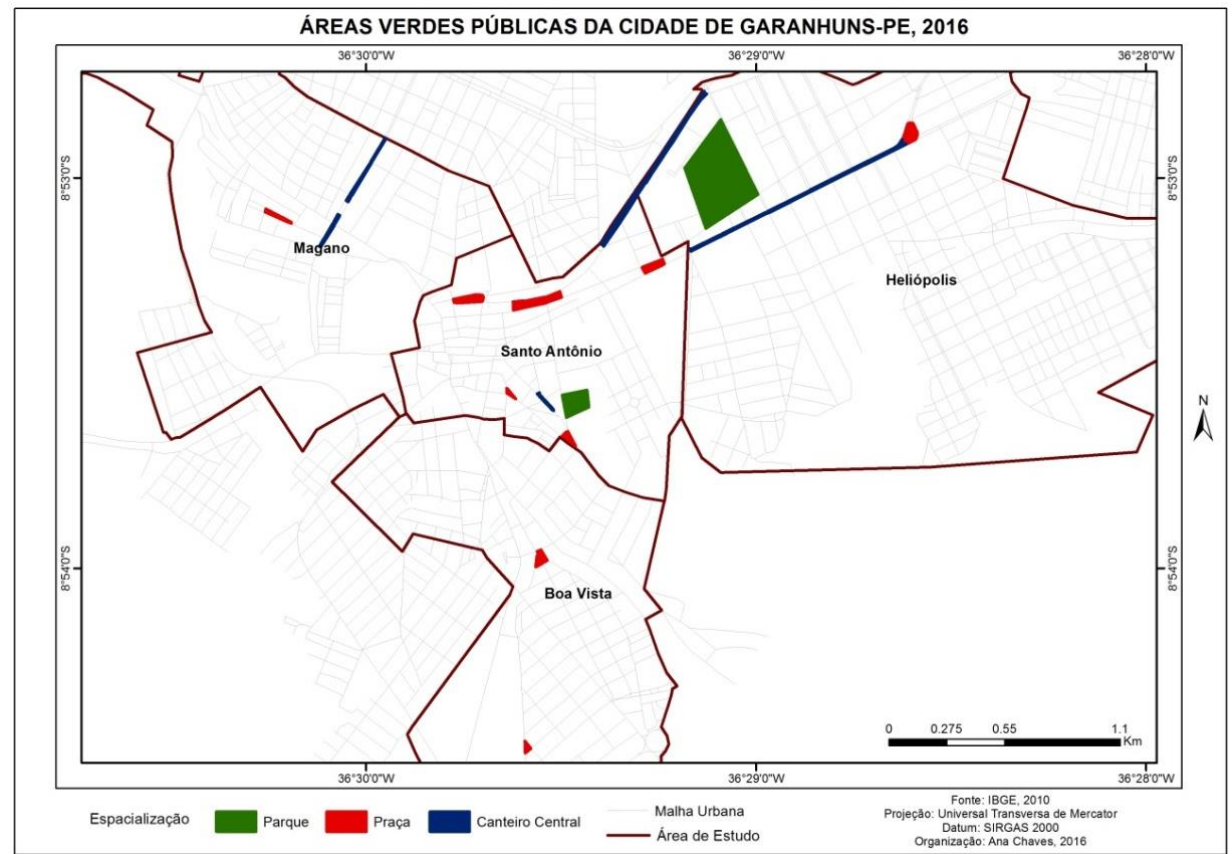

Figura 02: Espacialização das áreas verdes públicas na malha urbana de Garanhuns-PE. Fonte: Elaborado pelas autoras (2016).

As áreas verdes públicas correspondem a quatro canteiros centrais, nove praças e dois parques, essas localizadas nos bairros Boa Vista, Magano, Heliópolis e Santo Antônio, contemplando diferentes tamanhos (tabela 01).

Oliveira (1996) considera que as áreas verdes são áreas permeáveis, compostas predominantemente por cobertura vegetal arbórea ou arbustiva com funções potenciais de:

$\checkmark$ Lazer - Proporciona um microclima distinto no meio urbano em relação à luminosidade, temperatura e outros parâmetros associado ao bem-estar humano;

$\checkmark$ Ecológica - Possibilitando uma estabilidade geomorfológica, amenização da poluição e que suporte uma fauna urbana;

$\checkmark$ Estética - Constituem elementos estéticos marcantes na paisagem independente da estrutura ou enquadramento social da área. 
Tabela 01: Características das áreas verdes públicas da cidade de Garanhuns-PE.

\section{ÁREAS VERDES PÚBLICAS DE GARANHUNS-PE}

\begin{tabular}{|c|c|c|c|c|}
\hline Bairro & Área verde (Nome) & Área $\left(\mathbf{m}^{2}\right)$ & Extensão (m) & Altitude (m) \\
\hline \multirow{2}{*}{ Boa Vista } & Praça Maceió & $2.110,909 \mathrm{~m}^{2}$ & $87 \mathrm{~m}$ & $864 \mathrm{~m}$ \\
\hline & $\begin{array}{c}\text { Praça Universitária } \\
\text { UFRPE }\end{array}$ & $820,561 \mathrm{~m}^{2}$ & $50 \mathrm{~m}$ & $849 \mathrm{~m}$ \\
\hline \multirow[t]{2}{*}{ Magano } & $\begin{array}{c}\text { Canteiro da Avenida Santa } \\
\text { Terezinha }\end{array}$ & $6.307,167 \mathrm{~m}^{2}$ & $1088 \mathrm{~m}$ & $946 \mathrm{~m}$ \\
\hline & Praça Campus Sales & $1.507,083 \mathrm{~m}^{2}$ & $138 \mathrm{~m}$ & $893 \mathrm{~m}$ \\
\hline \multirow{4}{*}{ Heliópolis } & $\begin{array}{c}\text { Canteiro da Avenida Rui } \\
\text { Barboza }\end{array}$ & $10.507,58 \mathrm{~m}^{2}$ & $1175 \mathrm{~m}$ & $882 \mathrm{~m}$ \\
\hline & Praça Tavares Correia & $4.773,93 \mathrm{~m}^{2}$ & $100 \mathrm{~m}$ & $887 \mathrm{~m}$ \\
\hline & Parque Euclides Dourado & $92.731,40 \mathrm{~m}^{2}$ & $344 \mathrm{~m}$ & $887 \mathrm{~m}$ \\
\hline & $\begin{array}{c}\text { Canteiro da Avenida } \\
\text { Caruaru }\end{array}$ & $10.608,603 \mathrm{~m}^{2}$ & $867 \mathrm{~m}$ & $876 \mathrm{~m}$ \\
\hline \multirow{7}{*}{ Santo Antônio } & \begin{tabular}{|c|} 
Canteiro da Rua Severino \\
Peixoto \\
\end{tabular} & $688,187 \mathrm{~m}^{2}$ & $108 \mathrm{~m}$ & $827 \mathrm{~m}$ \\
\hline & Praça São Francisco & $593,703 \mathrm{~m}^{2}$ & $59 \mathrm{~m}$ & $833 \mathrm{~m}$ \\
\hline & Praça Dr. Aloísio Pinto & $1.239,95 \mathrm{~m}^{2}$ & $76 \mathrm{~m}$ & $802 \mathrm{~m}$ \\
\hline & Praça Dom Moura & $6.739,43 \mathrm{~m}^{2}$ & $232 \mathrm{~m}$ & $872 \mathrm{~m}$ \\
\hline & $\begin{array}{l}\text { Praça Monsenhor Adel- } \\
\text { mar da Mota Valença }\end{array}$ & $3.884,42 \mathrm{~m}^{2}$ & $141 \mathrm{~m}$ & $871 \mathrm{~m}$ \\
\hline & Praça Solto Filho & $3.024,22 \mathrm{~m}^{2}$ & $103 \mathrm{~m}$ & $871 \mathrm{~m}$ \\
\hline & $\begin{array}{c}\text { Parque Ruber Van Der } \\
\text { Linden }\end{array}$ & $10.999,60 \mathrm{~m}^{2}$ & $114 \mathrm{~m}$ & $820 \mathrm{~m}$ \\
\hline
\end{tabular}

Fonte: Elaborado pelas autoras (2017).

As áreas verdes proporcionam um microclima na cidade que possibilita a população desenvolver atividades voltadas ao lazer na forma de recreação com a família, amigos ou sozinho, como: contemplar a paisagem, passeios, piqueniques, levar as crianças para brincar; atividades físicas como: caminhada, corrida, jogar vôlei, futsal, quando a área disponibilizar playground e equipamentos esportivos e descanso na hora de ócio.

As AVPs possuem papel paisagístico no embelezando de prédios históricos e em frente aos edifícios. E, com relação ao tempo, quando proporciona a amenização da temperatura, contribui como barreira para o vento, amortização do impacto das chuvas e facilitam a infiltração da mesma no solo, diminui os ruídos e absorve parte da poluição em suspensão no ar. 


\section{Procedimentos metodológicos da pesquisa}

A abordagem sistêmica como perspectiva metódica no âmbito da geografia física para trabalhos referentes à temática ambiental é relativamente recente (MENDONÇA, 2002).

A introdução do enfoque sistêmico na Geografia vem a contribuir para investigações que também levem em consideração as ações antrópicas em pesquisas ambientais, possibilitando a realização de estudos referentes ao complexo de interações entre os elementos naturais e humanos verificáveis na paisagem, o que possibilita análise e interpretação da realidade por meio das "abordagens analítico-integradas" (OLIVEIRA; MELO E SOUZA, 2012, p. 158).

Assim, este estudo fundamentou-se na visão sistêmica, pautada na complexidade das discussões envolvendo as funções sociais e os elementos naturais do ambiente urbano para análise das áreas verdes públicas da cidade de Garanhuns-PE. Estando dividido em duas etapas, o trabalho de campo e de gabinete:

Trabalho de gabinete - Realização de leituras a respeito do tema e objeto de estudo escolhido, fomentando, assim, um conjunto de conceitos e teorias para composição da contextualização teórica e formando o alicerce de conhecimento dos caminhos que deveriam ser trilhados, e a análise, interpretação e elucidação dos dados obtidos na parte teórica e prática da pesquisa:

Confecção de mapas temáticos (MARTINELLI, 2013) da área de estudo, das áreas verdes e do tipo de adensamento urbano, fazendo-se uso das ferramentas e técnicas de geoprocessamento, operacionalizadas em ambiente dos Sistemas de Informações Geográficas (SIGs) por meio de dados vetoriais e matriciais obtidos no Instituto Brasileiro de Geografia e Estatística (IBGE) e os dados obtidos nos trabalhos de campo com o suporte de Sistema de Posicionamento Global (GPS), câmera fotográfica, trena, diário de campo e dados fornecidos por Melo e Melo e Souza (2015), foram manuseados através dos softwares ArcGIS 10.2.1, Global Mapper 16 e QGIS.

Trabalho de campo - Engloba o trabalho de campo com o suporte de equipamentos para registros fotográficos e captação de localização geográfica, como câmara fotográfica e GPS, imprescindíveis à identificação das áreas verdes públicas e a observação da dinâmica das mesmas:

Visitas aos órgãos públicos, responsáveis pela administração dos locais aqui considerados objetos de estudo: secretaria de meio ambiente e secretaria de planejamento.

Para melhor análise e interpretação da estrutura das áreas verdes elaborou-se uma lista de verificação em campo (checklists), como medida de mensuração dos 
aspectos estruturais, paisagísticos, usos sociais e o adensamento urbano das áreas verdes públicas da cidade de Garanhuns.

De acordo com Oliveira e Melo e Souza (2007, p. 96), “a aplicação das checklists dá-se por meio de registro de campo feito por observadores selecionados a partir de critérios de possuírem conhecimentos gerais e específicos sobre assuntos referentes à pesquisa".

A lista de verificação em campo foi organizada a partir de um pré-campo no qual se selecionaram variáveis observáveis na paisagem que possibilitassem verificar a dinâmica social das áreas verdes (quadro 01).

Quadro 01: Lista de Verificação em Campo.

\begin{tabular}{|c|c|}
\hline \multicolumn{2}{|c|}{ LISTA DE VERIFICAÇÃO EM CAMPO - CHECKLIST } \\
\hline Adensamento das áreas verdes & $\begin{array}{l}\text { Construções arquitetônicas do entorno } \\
\text { onde estão inseridas as AVPs }\end{array}$ \\
\hline Usos sociais das áreas verdes & $\begin{array}{l}\text { As atividades que os frequentadores } \\
\text { realizam nas AVPs }\end{array}$ \\
\hline
\end{tabular}

Fonte: Elaborado pelas autoras (2015).

A partir da presente lista de verificação em campo, traçou-se campos sequente, sem datas fixas, mas em meses seguidos, permitindo a realização de análise das áreas verdes públicas durante todos os dias da semana, no horário da manhã e tarde. Por motivo de segurança, não se realizou campo no horário da noite.

Foi por meio desses campos que se fizeram as observações e anotações dos usos sociais desenvolvidos pelos frequentadores das áreas verdes estudadas. E, também, se observou os demais elementos determinados na checklist, dando ênfase ao adensamento urbano no entorno das áreas verdes.

\section{Adensamento urbano das áreas verdes públicas da cidade de Garanhuns-PE}

A cidade de Garanhuns é composta por doze bairros, desses apenas quatros são detentores das principais áreas verdes públicas. Isso evidencia que a "cidade das flores", como é conhecida turisticamente Garanhuns, limita suas flores a apenas um terço de seus bairros, sendo o bairro central o com maior quantitativo de AVPs.

As áreas verdes públicas estudadas estão distribuídas por quatro bairros: Boa Vista, Magano, Heliópolis e Santo Antônio. A maior concentração de árvores se dá nos bairros que possuem os parques e os canteiros centrais de avenidas extensas (tabela 02). 
Tabela 02: Total de Indivíduos Arbóreos por Área Verde.

\begin{tabular}{c|c|c|c}
\hline \multicolumn{4}{|c}{ DISTRIBUIÇ̃̃O DAS ÁREAS VERDES POR BAIRRO } \\
\hline Bairros & Área total do bairro $\left(\mathrm{m}^{2}\right)$ & Áreas verdes Tipos/Quantidades & Total de indivíduos arbóreos \\
\hline Boa Vista & $265.637,0$ & 2 Praças / 2 & 37 \\
\hline Magano & $203.820,0$ & 1 Canteiro central e 1 Praça / 2 & 63 \\
\hline Heliópolis & $401.700,0$ & $\begin{array}{c}\text { 2 Canteiro Central, 1 Praça e 1 } \\
\text { Parque / 4 }\end{array}$ & 2423 \\
\hline Santo Antônio & $118.737,0$ & $\begin{array}{c}\text { 2 Canteiros centrais, 5 Praças e 1 } \\
\text { Parque / 8 }\end{array}$ & 382 \\
\hline
\end{tabular}

Fonte: Elaborado pelas autoras (2016).

A maior concentração de AVPs ocorre no bairro Santo Antônio. Já a maior quantidade de indivíduos arbóreos encontra-se no bairro Heliópolis devido à presença do parque Euclides Dourado, que possui maior quantitativo de árvores.

O bairro Boa Vista possui apenas duas áreas verdes do tipo praça e com poucas árvores em sua constituição, assim esse bairro é o que apresenta menor quantia de árvores. Diagnosticou-se que a maior incidência de AVPs ocorre no bairro centro e também nas partes centrais dos próprios bairros.

Para verificar como se apresenta a atual espacialização das principais áreas verdes públicas de Garanhuns, elaborou-se uma matriz de espacialização para mostrar a distância existente entre essas (tabela 03).

Tabela 03: Matriz de Espacialização das Áreas Verdes Públicas.

MATRIZ DE ESPACIALIZAÇÃO DAS ÁREAS VERDES PÚBLICAS (KM)

\begin{tabular}{c|c|c|c|c|c|c|c|c|c|c|c|c|c|c|c}
\hline- & AVP 1 & AVP 2 & AVP 3 & AVP 4 & AVP 5 & AVP 6 & AVP 7 & AVP 8 & AVP 9 & AVP 10 & AVP 11 & AVP 12 & AVP 13 & AVP 14 & AVP 15 \\
\hline AVP 1 & 0 & 0,90 & 1,93 & 2,03 & 2,12 & 2,66 & 1,98 & 1,90 & 0,73 & 0,79 & 0,58 & 1,21 & 1,26 & 1,48 & 0,74 \\
AVP 2 & 0,90 & 0 & 2,71 & 2,77 & 2,88 & 3,42 & 2,82 & 2,79 & 1,64 & 1,67 & 1,48 & 2,11 & 2,14 & 2,35 & 2,82 \\
AVP 3 & 1,93 & 2,71 & 0 & 0,33 & 2,05 & 2,66 & 1,75 & 1,46 & 1,33 & 1,18 & 1,53 & 1,00 & 0,74 & 1,47 & 1,43 \\
AVP 4 & 2,03 & 2,77 & 0,33 & 0 & 2,39 & 3,00 & 2,11 & 1,78 & 1,52 & 1,36 & 1,69 & 1,26 & 0,99 & 1,77 & 1,65 \\
AVP 5 & 2,12 & 2,88 & 2,05 & 2,39 & 0 & 0,01 & 0,07 & 0,42 & 0,99 & 1,09 & 1,03 & 0,78 & 1,08 & 0,19 & 0,91 \\
AVP 6 & 2,66 & 3,42 & 2,66 & 3,00 & 0,01 & 0 & 0,92 & 1,01 & 2,12 & 2,24 & 2,15 & 1,92 & 2,20 & 1,34 & 2,03 \\
AVP 7 & 1,93 & 2,82 & 1,75 & 2,11 & 0,07 & 0,92 & 0 & 0,12 & 1,30 & 1,37 & 1,38 & 1,02 & 1,28 & 0,40 & 1,24 \\
AVP 8 & 1,90 & 2,79 & 1,46 & 1,78 & 0,42 & 1,01 & 0,12 & 0 & 0,78 & 0,83 & 0.91 & 0,41 & 0,67 & 0,26 & 0,78 \\
AVP 9 & 0,73 & 1,64 & 1,33 & 1,52 & 0,99 & 2,12 & 1,30 & 0,78 & 0 & 0,13 & 0,15 & 0,43 & 0,54 & 0,82 & 0,09 \\
AVP 10 & 0,79 & 1,67 & 1,18 & 1,36 & 1,09 & 2,24 & 1,37 & 0,83 & 0,13 & 0 & 0,32 & 0,43 & 0,48 & 0,89 & 0,29 \\
AVP 11 & 0,53 & 1,48 & 1,53 & 1,69 & 1,08 & 2,15 & 1,38 & 0,91 & 0,15 & 0,32 & 0 & 0,64 & 0,78 & 0,90 & 0,11 \\
AVP 12 & 1,21 & 2,11 & 1,00 & 1,26 & 0,78 & 1,92 & 1,02 & 0,41 & 0,43 & 0,43 & 0,64 & 0 & 0,22 & 0,58 & 0,51 \\
AVP 13 & 1,26 & 2,14 & 0,74 & 0,99 & 1,08 & 2,20 & 1,28 & 0,67 & 0,54 & 0,48 & 0,78 & 0,22 & 0 & 0,85 & 0,69 \\
AVP 14 & 1,43 & 2,35 & 1,47 & 1,77 & 0,19 & 1,34 & 0,40 & 0,26 & 0,82 & 0,89 & 0,90 & 0,58 & 0,85 & 0 & 0,73 \\
AVP 15 & 0,74 & 2,82 & 1,43 & 1,65 & 0,91 & 2,03 & 1,24 & 0,78 & 0,09 & 0,29 & 0,11 & 0,51 & 0,69 & 0,73 & 0 \\
\hline
\end{tabular}

Fonte: Elaborado pelas autoras (2016).

Informações: AVP 1 Praça Maceió; AVP 2 Praça Universitária UFRPE; AVP 3 Canteiro da Avenida Santa Terezinha; AVP 4 Praça Campus Sales; AVP 5 Canteiro da Avenida Rui Barboza; AVP 6 Praça Tavares Correia; AVP 7 Parque Euclides Dourado; AVP 8 Canteiro da Avenida Caruaru; AVP 9 Canteiro da Rua Severino Peixoto; AVP 10 Praça São Francisco; AVP 11 Praça Dr. Aloísio Pinto; AVP 12 Praça Dom Moura; AVP 13 Praça Monsenhor Adelmar da Mota Valença; AVP 14 Praça Solto Filho; AVP 15 Parque Ruber Van Der Linden. 
A matriz de espacialização comporta a distância $(\mathrm{Km})$ entre as áreas verdes públicas e possibilita visualizar a distribuição espacial das mesmas. Observa-se que existem outras praças e canteiros centrais na malha urbana de Garanhuns que não foram mapeados, uma vez que esses são imperializados ou apresentam pouca composição de solo permeável e/ou com vegetação assim não se classificam como áreas verdes, ou seja, os objetos de análise investigados.

Na matriz, a Praça Universitária (UFRPE) e a Praça Tavares Correia são as de maior distância, com 3,42 km. Já a distância entre a Praça Tavares Correia e a Avenida Rui Barboza é a menor existente, $0,01 \mathrm{Km}$. No bairro Boa Vista, a distância entre as praças Universitária (UFRPE) e a Maceió é de 0,90 Km. Já para o bairro Magano, a distância entre as áreas verdes é de $0,33 \mathrm{Km}$.

A Praça Tavares Correia e Av. Rui Barbosa são as áreas verdes públicas mais próximas $(0,01 \mathrm{Km})$, localizam-se no bairro Heliópolis, para esse bairro a maior distância existente é de $0,42 \mathrm{Km}$, entre as os Canteiros Centrais das Avenidas Caruaru e Rui Barboza.

No bairro Santo Antônio a maior distância existente entre as AVPs é de 0,90 $\mathrm{Km}$, entre as Praças Solto Filho e Dr. Aloísio Pinto, essa última praça e o parque Ruber Van Der Lindem são as mais próximas nesse bairro, com distância de 0,11 Km.

Além da espacialização, as áreas verdes públicas estudadas apresentam adensamentos similares e distintos, onde podem predominar atividades comerciais ou ter função residencial (figura 03).

As áreas verdes localizadas nos bairros Boa Vista e Magano apresentam um adensamento urbano do tipo residencial, composto por:

> Predominante: residências de estrutura térrea com poucas construções de primeiro a até o terceiro andar;

$>$ Pouco: pequenos comércios como restaurantes e mercadinhos;

> Destaque: Instituições de ensino básico no bairro Magano e ensino superior ao lado da Praça Universitária UFRPE.

No bairro Heliópolis, o adensamento prevalecente é do tipo comercial, constituído por:

$>$ Predominante: comércio variado como, por exemplo, mercados, lojas de autopeças de veículos, borracharias, academia, restaurantes, bancos, lojas de material de construção e de móveis;

> Pouco: apresenta poucas residências, sendo essas térreas ou até segundo andar; 
Destaque: ampla presença de hotéis, elevando o adensamento com prédios de três andares, rodoviária municipal, instituição de ensino básico e superior próximo ao Parque Euclides Dourado e dos Canteiros Centrais das Avenidas Rui Barboza e Caruaru, presença da Gerência Regional de Educação de Pernambuco ao lado da Praça Tavares Correia.

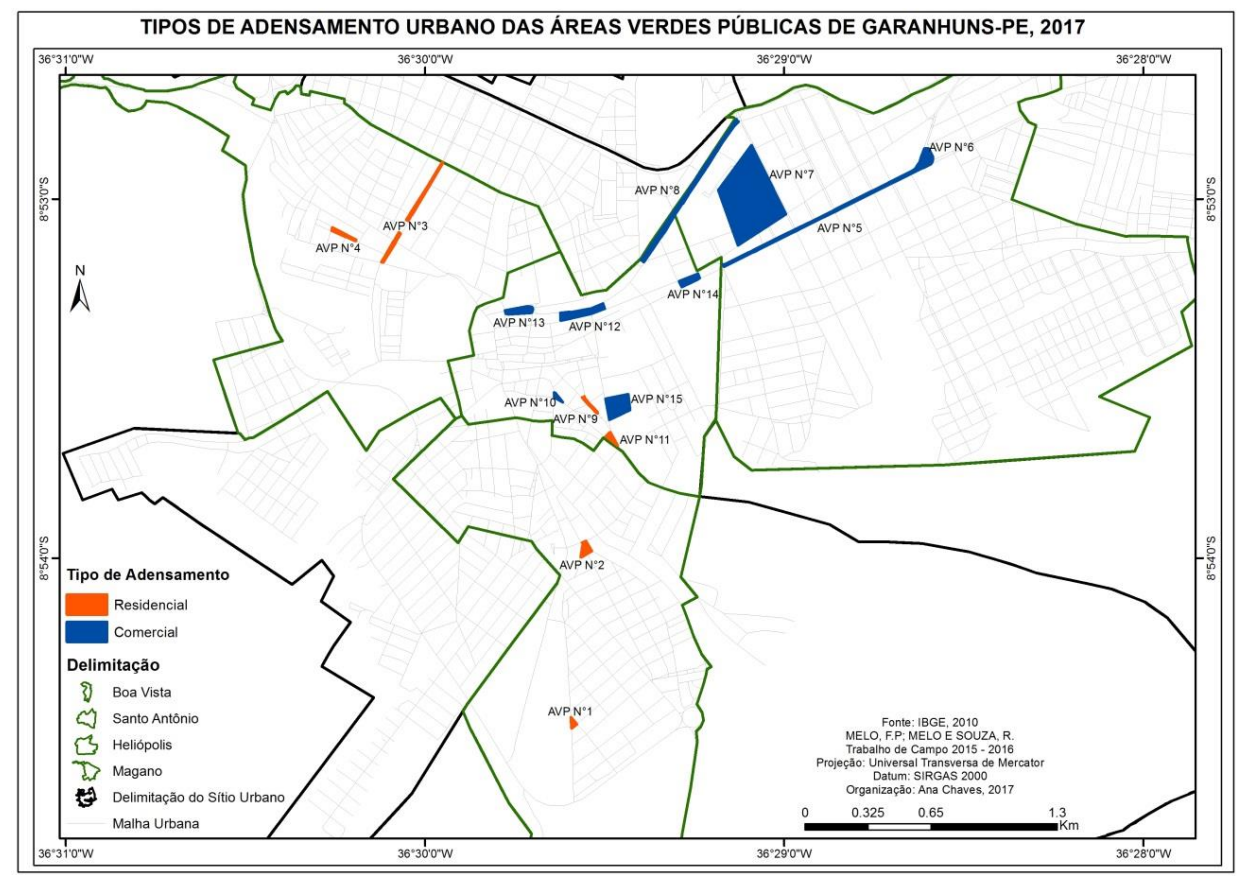

Figura 03: Tipos de adensamento urbano nas áreas verdes públicas em Garanhuns-PE. Fonte: Elaborado pelas autoras (2017).

Santo Antônio é o bairro centro da cidade de Garanhuns e apresenta a maior concentração de áreas verdes públicas estudadas (sete, no total). Nele subsiste concomitantemente o adensamento do tipo residencial e o comercial.

O Canteiro da Rua Severino Peixoto e a Praça Dr. Aloísio Pinto são do tipo residencial, AVPs não centrais. As características do adensamento são:

Predominante: adensamento residencial, com casas de estrutura térrea e poucas construções de primeiro e segundo andar;

$>$ Pouco: comércio, sendo este com pouca relevância sem presença de mercadinho, visto que essas áreas verdes encontram-se próximas as principais áreas comerciais da cidade; 
Destaque: tem proximidade a uma escola municipal pública e no terreno limite com outro bairro visualiza-se a construção de prédios de até terceiro andar, com estruturas simples no pé da encosta, lugar inadequado a habitação.

Já as Praças São Francisco, Dom Moura, Monsenhor Adelmar da Mota Valença, Solto Filho e o Parque Ruber Van Der Linden são áreas verdes bem centrais e cercadas por adensamento comercial onde:

Predominante: adensamento de construções comerciais que variam de edifícios térreos, os predominantes, a edifícios de até terceiro andar; possui todo tipo de comércio, desde produtos domésticos, de construção, óticas, material de informática, lanchonetes, bares, restaurantes, depósitos, pousadas, hotéis entre outros;

$>$ Pouco: por se tratar do principal centro comercial, poucas são as residências que permanecem nessas áreas. Essas são do tipo térreo com poucas casas de primeiro andar, algumas delas apresentando fachada arquitetônica histórica.

$>$ Destaque: instituições privadas de ensino fundamental em médio tradicionais da cidade ao lado das Praças Solto Filho e Monsenhor Adelmar da Mota Valença. Nessa última, localiza-se um posto da polícia civil de Pernambuco; a Previdência Social, o Centro Cultural e o Instituto de Histórico e Geográfico, no entorno da Praça Dom Moura; o Parque Ruber Van Der Linden divide muro com o SESC Garanhuns.

O sítio urbano da cidade de Garanhuns localiza-se sobre um substrato natural de morros e vales profundos, não possui uma morfologia adequada para construção de edifícios altos. No entanto se observar na paisagem urbana recente que a cidade começa a se verticalizar, principalmente, no entorno das instituições de ensino superior.

Com exceção das Praças Universitária UFRPE e Dr. Aloísio Pinto, as demais AVPs estudadas encontram-se consolidadas em locais nos quais o adensamento horizontal não é possível. Entretanto, por predominar construções térreas, torna-se possível a realização do adensamento vertical, embora esse não seja algo recomendável, devido aos aspectos morfológicos da cidade.

Coloca-se em questão o fato de maior adensamento comprometer as poucas áreas permeáveis presentes na cidade, o que leva a diminuição da qualidade ambiental. No caso do adensamento vertical, a situação também é crítica, pois evita a circulação de ar dentro da cidade, contribuindo para formação de ilhas de calor, provocando desconforto térmico nos dias quentes e representando um fator negativo na paisagem urbana. 
$\mathrm{O}$ adensamento pode dificultar a troca de energia entre as áreas verdes, quando estas ficam restritas e muradas por altas construções, o que dificultará a circulação do vento no ambiente urbano. E não se pode deixar de fora o fato das AVPs não serem destinadas apenas para a manutenção da qualidade ambiental urbana, haja vista que também são espaços essenciais aos usos sociais múltiplos e diferentes tipos de lazer.

\section{Usos sociais de áreas verdes públicas da Cidade de Garanhuns-PE}

Um dos fatores que contribui para maior possibilidade de usos das áreas verdes públicas é a presença de equipamentos que permitam maiores possibilidades de lazer, algo verificado apenas nos parques urbanos.

Nas áreas verdes públicas analisadas, constatou-se que predomina a possibilidade de se desenvolver o lazer passivo, pois são, em sua maioria, do tipo praça e canteiro central.

No tocante aos canteiros centrais de Rua Severiano Peixoto e a Avenida Santa Terezinha, Caruaru e Rui Barbosa, os usos sociais deveriam se restringir a circulação de pedestre, por ser uma área verde em contato direto com a poluição advindas dos meios de transportes.

Contudo, é fácil verificar a permanência de algumas pessoas conversando nos canteiros por algum tempo, ou até ficarem a desfrutar da sombra proporcionada pelas árvores. Usos sociais incompatíveis com o local (figura 04).
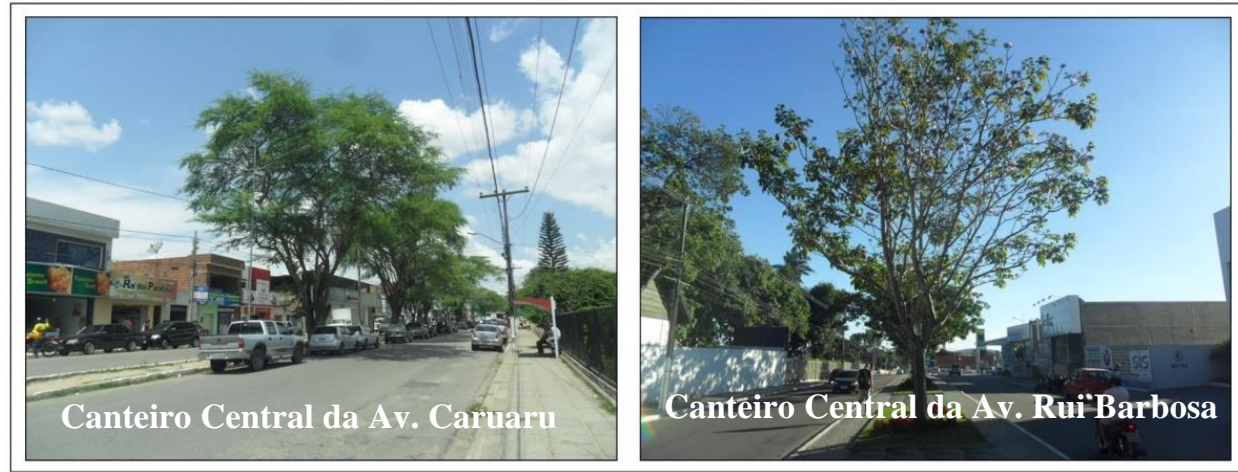

Figura 04: Canteiros centrais.

Fonte: fotografias das autoras (2016).

Já no que diz respeito a acessibilidade, a mesma só existe no Canteiro Central da Avenida Rui Barbosa, essa área verde mantém uma proporcionalidade regular no entorno de cinco metros de largura. Nos demais Canteiros, trechos dos canteiros só tem o espaço da arborização, impossibilitando a circulação de pessoas pelo mesmo. 
As praças, por sua vez, são compostas por diferentes extratos de vegetação, algumas apresentam bustos referentes a algumas autoridades, como equipamento de uso social, só se verificou a presença de bancos e caramanchões (figura 05).

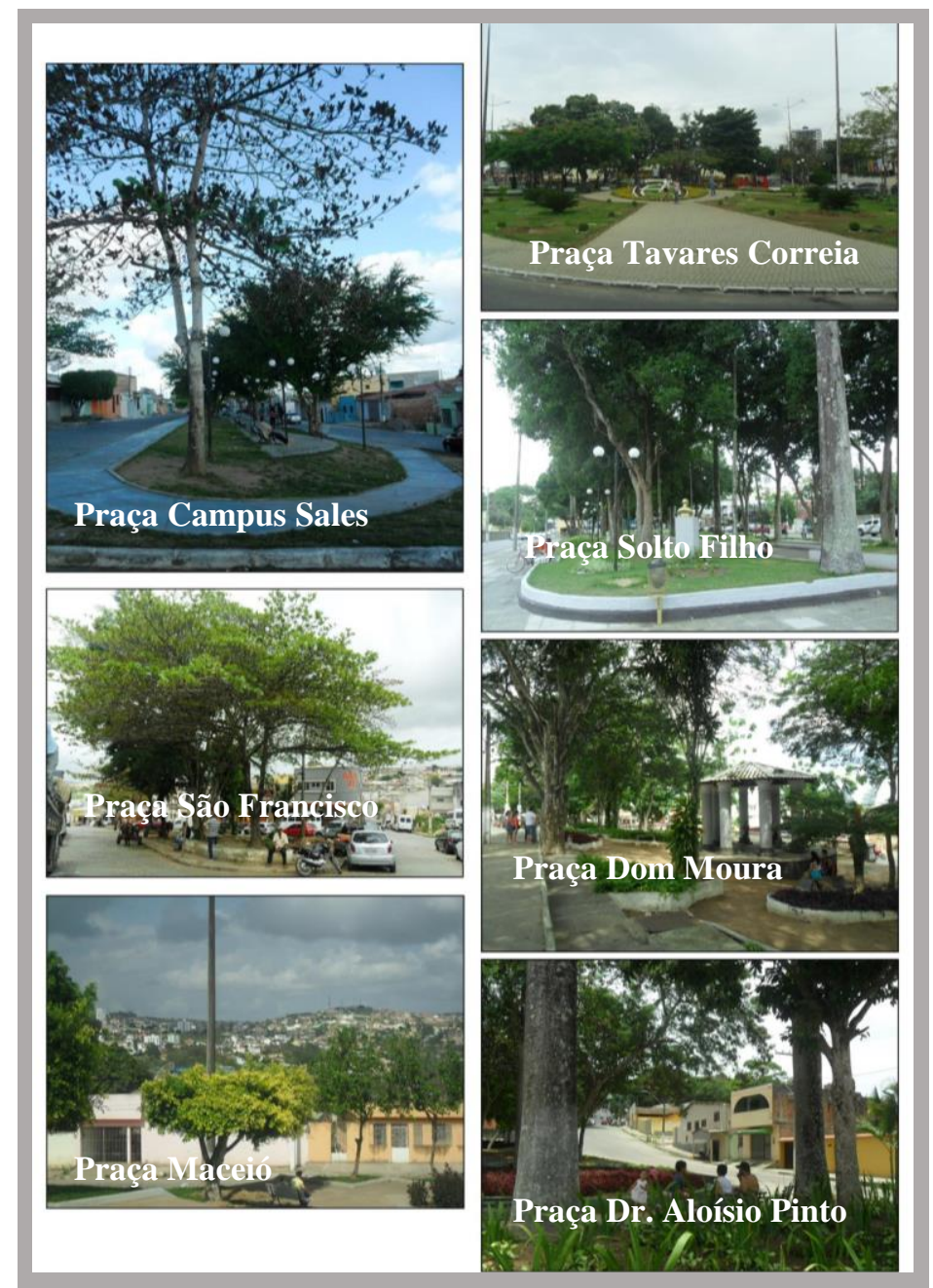

Figura 05: Praças Urbanas.

Fonte: fotografias das autoras (2015/2016).

No entanto, algumas praças dispõem de espaço nos quais poderiam ser introduzidos playground para o lazer ativo de crianças e equipamentos de exercícios físicos para os adultos, possibilitando maior diversidade de usos sociais para as mesmas. 
Durante as observações de campo, constatou-se que os usos sociais realizados pelos frequentadores das praças são: circulação das pessoas, permanência e contemplação da paisagem pelos frequentadores; descanso no horário de almoço; ponto de encontro de casais e grupos de amigos de toda faixa etária; jovens andar de bicicleta e crianças brincam pelas praças mesmo sem de playground; pessoas esperando ônibus ou transportes alternativos; nas praças mais afastadas do centro da cidade são frequentadas principalmente pelos moradores do entorno.

Quando a presença de praças próxima de instituições de ensino, os estudantes estão entre os principais frequentadores dessas praças nos horários que antecedem as aulas, bem como, na saída da escola.

Os parques urbanos possibilitam tanto a realização do lazer ativo como o passivo em conjunto para as crianças. Sendo que o Parque Ruber Van Der Linden não possui equipamento destinado ao lazer ativo de adultos (figura 06).
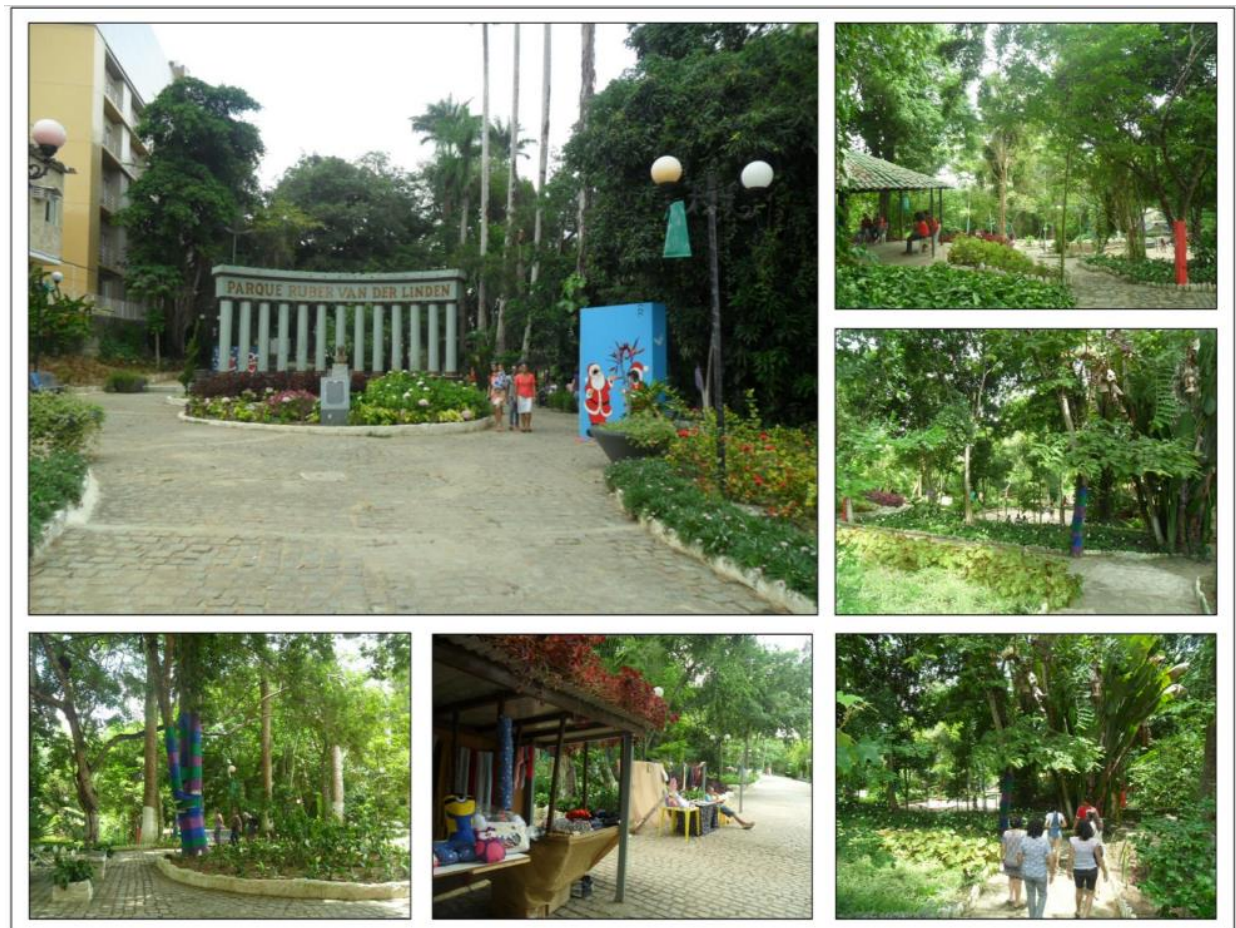

Figura 06: Parque Ruber Van Der Linden.

Fonte: fotografias das autoras $(2015 / 2016)$.

O parque Ruber Van Der Linden está localizado sobre uma encosta. A maioria de seus acessos se dá através de escadarias ou vias de circulação inclinadas com piso de 
paralepípedos, o que dificulta o acesso dessa AVP as pessoas que necessitam de acessibilidade, como cadeirantes, idosos e crianças pequenas.

Os usos sociais verificados nesse parque são: encontros de casais e amigos em toda faixa etária; pais com filhos em todas as idades, turistas, grupos de senhoras e senhores passeando; realização de ensaios fotográficos; crianças brincam no playground ou pelo parque; pessoas descansando ou contemplando a paisagem no horário livre.

O Parque Euclides Dourado, por sua vez, dispõe de maior diversidade de lazer, pois é equipado por muitos equipamentos de usos sociais. Por essa razão, possibilita o lazer ativo e passivo para todas as faixas etárias. No seu interior existe a presença de playground, quadras poliesportivas, pista de cooper, skate, três conjuntos equipamentos de academia para exercícios físicos e bancos espalhados pelo parque (figura 07).

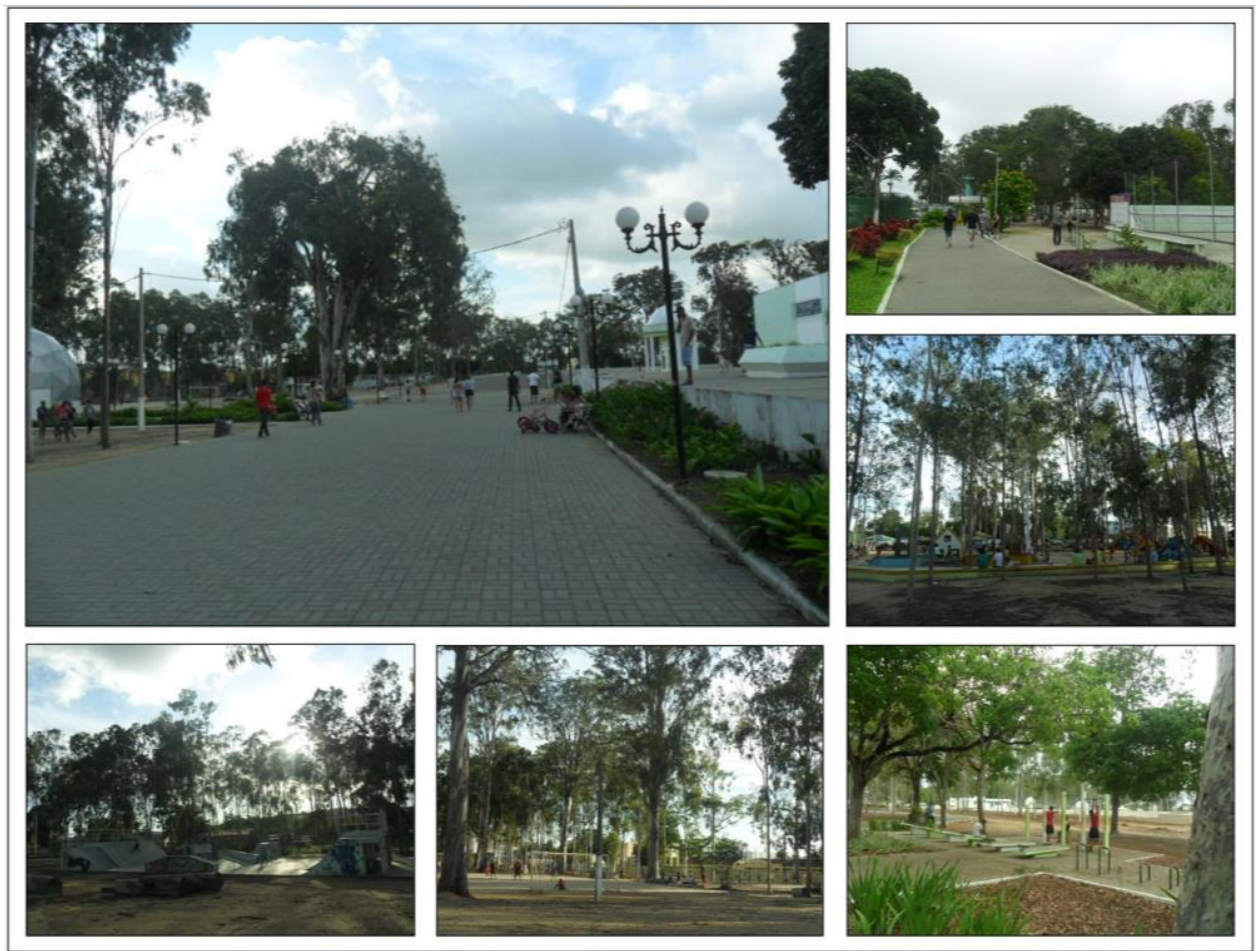

Figura 07: Parque Euclides Dourado.

Fonte: fotografias das autoras (2015/2016).

Nesse parque, todos os dias pessoas passeiam, fazem exercícios físicos, caminhada e corrida. Os frequentadores idosos costumam frequentar o parque para se exercitarem pela manhã, para aproveitar o momento com menor temperatura no dia. 
As quadras e pistas de skate pouco são usadas durante a semana. Quando são, os usos normalmente ocorrem no final da tarde por adolescentes e alguns adultos. Durante todos os dias de campo no parque, encontrou-se grupos jovens reunidos e casais de namorados. No entanto, não se verificou crianças brincado no playground todos os dias.

Aos finais de semana é verificado maior quantidade de frequentadores nos parques. Sendo que aos domingos acontece uma feirinha com artesanatos e produtos confeccionados pelos artesões locais, da cidade de Garanhuns e região no Ruber Van Der Linden.

Coloca-se em destaque que, todos os usos sociais possíveis no espaço do Parque Euclides Dourado se concretizam no final da semana. Como a cidade não dispõe de nenhum outro tipo de espaço público equipado para o desenvolvimento do lazer, a população de Garanhuns e das cidades vizinhas encontram nessa área verde um lugar de encontro, descanso e recreação, através de piqueniques, realização de atividades esportivas ou simples contemplação da paisagem.

E para dar suporte ao quantitativo de frequentadores nos finais de semana, vendedores de picolé, sorvete, algodão doce, água de coco, doces, salgados, lanches variados e vendedores de balões e bichos de pelúcia vão para o parque, possibilitando que as pessoas tenham acesso a essa gama de possibilidades, permanecendo por mais tempo no local.

Nele, a presença da biblioteca pública e do planetário são fatores fundamentais para encontrar estudantes e grupos escolares em passeios ou visita escolar no parque. São eles que possibilitam o uso social ligado a atividades educacionais, pois é normal encontrar estudantes em grupo ou individualmente estudando na biblioteca todos os dias, já que no entorno do parque se localizam duas escolas do ensino básico.

A presença de banheiros públicos, quiosques e ou restaurantes no interior dos parques contribui para permanência das pessoas por tempos prolongados nessas áreas, pois se atende às necessidades fisiológicas dos indivíduos.

Como síntese dos usos sociais observados nas áreas verdes estudadas o quadro dois demonstra os tipos de lazer exercido nas AVPs e apontam as atividades que poderiam ser efetivadas nas mesmas, potencializando assim os usos sociais (quadro 02).

Verifica-se que as áreas verdes públicas da cidade de Garanhuns, representadas pelas praças, parques e canteiros centrais correspondem a espaços livres de usos sociais múltiplos, principalmente quando são áreas contempladas por equipamentos esportivos, playground, bancos entre outros equipamentos alternativos para o uso comum, dos frequentadores dessas áreas. 
Quadro 02: Usos Sociais das Áreas Verdes Públicas.

\begin{tabular}{|c|c|c|c|c|c|}
\hline \multicolumn{6}{|c|}{ USOS SOCIAIS DAS ÁREAS VERDES PÚBLICAS } \\
\hline Bairro & Área Verde Pública & $\begin{array}{l}\text { Lazer } \\
\text { Ativo }\end{array}$ & $\begin{array}{c}\text { Lazer } \\
\text { Passivo }\end{array}$ & $\begin{array}{c}\text { Circulação } \\
\end{array}$ & $\begin{array}{c}\text { Possibilidade } \\
\text { de Lazer }\end{array}$ \\
\hline \multirow{2}{*}{ Boa Vista } & Praça Maceió & & & - & Sim/Ativo \\
\hline & $\begin{array}{c}\text { Praça Universitária } \\
\text { UFRPE }\end{array}$ & & & & Não \\
\hline \multirow{2}{*}{ Magano } & $\begin{array}{l}\text { Canteiro da Avenida } \\
\text { Santa Terezinha }\end{array}$ & & & S & Não \\
\hline & Praça Campus Sales & & & & Não \\
\hline \multirow{3}{*}{ Heliópolis } & $\begin{array}{c}\text { Canteiro da Avenida } \\
\text { Ruí Barboza }\end{array}$ & & & & Não \\
\hline & Praça Tavares Correia & & & & Não \\
\hline & $\begin{array}{l}\text { Parque Euclides } \\
\text { Dourado }\end{array}$ & बิ & & & Já Existem \\
\hline $\begin{array}{c}\text { Heliópolis / Santo } \\
\text { Antônio }\end{array}$ & $\begin{array}{c}\text { Canteiro da Avenida } \\
\text { Caruaru }\end{array}$ & & & & Não \\
\hline \multirow{7}{*}{ Santo Antônio } & $\begin{array}{l}\text { Canteiro da Rua } \\
\text { Severino Peixoto }\end{array}$ & & & & Não \\
\hline & Praça São Francisco & & & & Não \\
\hline & Praça Dr ${ }^{\circ}$ Aloísio Pinto & & & & Não \\
\hline & Praça Dom Moura & & & - & Sim/Ativo \\
\hline & $\begin{array}{l}\text { Praça Monsenhor Adelmar } \\
\text { da Mota Valença }\end{array}$ & & & & Sim/Ativo \\
\hline & $\overline{\text { Praça Solto Filho }}$ & & & & Não \\
\hline & $\begin{array}{c}\text { Parque Ruber Van Der } \\
\text { Linden }\end{array}$ & ip & & 3 & $\begin{array}{l}\text { Sim/Ativo } \\
\text { para Adulto }\end{array}$ \\
\hline
\end{tabular}

Fonte: Elaborado pelas autoras (2017).

Diagnosticou-se que algumas áreas verdes podem potencializar seus usos sociais, caso seja implantado maior variedade de equipamentos, além dos bancos nas mesmas, como playground para as crianças e equipamento para exercícios físicos para os adultos. 
Infelizmente nem todas AVPs vão disponibilizar de equipamentos de uso coletivo para realização de atividades físicas e/ou recreativas. Oliveira e Mascaró (2007) enfatizam o fato de nos espaços mais distantes da região central das cidades são escassas dos equipamentos, os que existem, geralmente estão quebrados, faltam pinturas, manutenção do piso e do playground.

\section{Considerações finais}

As áreas verdes públicas das cidades se encontram nos encaixes dos arruamentos, esses estão em locais onde predominam residências ou o comércio. Cada área verde está cercada por um tipo de adensamento, podendo além de ser do tipo residência ou comércio (térreo, de primeiro andar ou mais).

Cada lugar possui uma especificidade e uma morfologia própria. No entanto, o desejável e aconselhável é que as áreas verdes públicas sejam, sempre que possível, conectadas por caminhos verdes, arborização de rua ou calçadas, melhorando, assim, a qualidade ambiental das cidades, principalmente quando essas vêm sendo adensadas.

As áreas verdes públicas constituem espaços dinâmicos que proporcionam maior funcionalidade à paisagem urbana. São destinadas a funções sociais diversas e, para tal, faz-se necessária a sua integração aos elementos naturais e equipamentos de usos múltiplos por pessoas de diferentes faixas etárias.

Oferece beleza à paisagem urbana, pela presença do verde e de ajardinamentos floridos, o que acrescenta um valor estético ao local em que as AVPs se localizam. E são fundamentais para a população que vive nas cidades que não podem ter acesso aos ambientes de lazer particulares e encontram nas praças e parques um lugar para descanso e recreação.

As praças analisadas em Garanhuns possuem a função de circulação e lazer passivo, pois dispõem de bancos à disposição da população. No entanto, foi verificado a presença de crianças brincando e adolescentes andando de bicicleta, ou seja, a realizar do lazer ativo.

Os canteiros são bem arborizados, tendo como principal função a ecológica e de circulação, pois sua localização fica entre vias de tráfegos, dois destes, o da Av. Rui Barboza e da Av. Caruaru, que corresponde a vias de intenso fluxo de veículos estando exposta a emissão direta de gases poluentes.

A presença dos dois parques urbanos com funcionalidades distintas atribui maior dinamicidade e qualidade ambiental a paisagem urbana pela presença da natureza concentrada em meio à artificialização do espaço construído. Sendo o Parque Ruber Van Der Linden composto por resquício de mata atlântica, no centro da cidade de Garanhuns, e o Parque Euclides Dourado com a dominância da espécie eucalipto. 
Nos parques existem maiores de opções usos, sendo o Euclides Dourado o mais diversificado, por dispor de quadras poliesportivas, equipamentos para exercícios físicos, pista de cooper e um playground bem diversificado.

AVPs estão localizadas predominantemente em ruas de caráter comercial e o adensamento predominante e de residências de estrutura térrea e poucos prédios com até o terceiro andar.

Apenas os parques equipamentos para o lazer passivo e ativo. Diante de tais circunstâncias, recomenda-se a instalação de equipamentos para o lazer ativo nas Praças Maceió, Tavares Correia, Dom Moura, Monsenhor Adelmar da Mota Valença e o Parque Ruber Van Der Linden, por essas disporem de espaço livre disponível para introdução de equipamentos que possam vir a beneficiar a população.

Assim, além de potencializar os usos sociais das áreas verdes com a inserção de equipamento, indica-se a necessidade de criar mais áreas verdes públicas na cidade de Garanhuns, do tipo praça e parques. Essas devem ser bem arborizadas e possibilitarem usos diversos, tanto para o lazer ativo como o passivo.

Aprimorar a capacidades das áreas verdes públicas, aumentar a quantidade e qualidade da arborização e dos equipamentos de usos sociais são ações práticas que contribuem para melhorar as condições sociais e ambientais da cidade de Garanhuns.

A qualidade de um espaço público precisa ser tanto na perspectiva ambiental como na social. As áreas verdes públicas apresentam entre suas atribuições a de manter e revitalizar a natureza e os elementos dessa, ar, água, vegetação, nos centros urbanos. Essa natureza deve subsistir ligada a um planejamento urbano que proporciona ambientes de usos sociais e equilíbrio ambiental concomitantemente.

\section{Referências bibliográficas}

ARFILLE, A. C. Áreas verdes lazer: considerações para sua compreensão e definição na atividade urbanística de parcelamento do solo. Revista de Direito Ambiental, v.9, n. 33, p. $33-51,2004$.

BARGOS, D. C. Mapeamento e análise das áreas verdes urbanas como indicador da qualidade ambiental urbana: estudo de caso de Paulínia-SP. 2010, 147f. Dissertação (Mestrado em Geografia) Universidade Estadual de Campinas, Instituto de Geociências. Campinas, 2010.

BRASIL. Novo código florestal. LEI, 12, 651, de 25 de Maio de 2012. Disponível em:<http://www.planalto.gov.br/ccivil_03/_ato2011-2014/2012/lei/112651.htm>. Acesso em: 17 dez 2016.

BRASIL. Estatuto da cidade. Brasília: Senado Federal, Subsecretaria de Edições Técnicas, 2001. Disponível em: 
<http://www.planalto.gov.br/ccivil_03/leis/LEIS_2001/L10257.htm>. Acesso em: 19 mar, 2015.

BRASIL, Ministério do Meio Ambiente (MMA). Áreas Verdes. Disponível em: <http://www.mma.gov.br/>. Acesso em: 05 de jul. de 2014.

BRASIL. Conselho Nacional do Meio Ambiente - CONAMA. Resolução n ${ }^{\circ} 369$, de 28 de março de 2006. Disponível em:

<http://www.mma.gov.br/port/conama/legiabre.cfm?codlegi=489> Acesso em: 10 de julho de 2015.

GIL, A. C. Métodos e Técnicas de pesquisa social. São Paulo: Atlas, 1987.

GOIS, D. V; FIGUEIREDO, M. L; MELO E SOUZA, R. Análise bioclimática e vulnerabilidade social urbana em áreas verdes públicas de Aracaju, Sergipe. Ateliê Geográfico, Goiânia, v. 8, n. 3, p.22-49, dez. 2014.

GOMES, M. A. S; SILVA, R. N.; SILVA, J. C. S; SILVA, T. G. F. Caracterização e análise dos espaços públicos da cidade de Arapiraca-AL-Brasil. Ateliê Geográfico, v. 6, n. 4, p.137-157, dez. 2012.

IBGE, Instituto Brasileiro de Geografia e Estatística. Censo 2010. Disponível em: <http://cidades.ibge.gov.br/xtras/home.php>. Acesso em: 25 de nov. de 2014.

IBGE, Instituto Brasileiro de Geografia e Estatística. Shapefile para download. Disponível em: <http://downloads.ibge.gov.br/downloads_geociencias.htm>. Acessado em: 17 de abril de 2015

MARTINELLI, M. Mapas da geografia e cartografia temática. 6 ed. São Paulo: Contexto, 2013.

MASCARENHAS, J. C.; BELTRÃO, B. A.; SOUZA JUNIOR, L. C.; GALVÃO, M. J. T. G.; PEREIRA, S. N.; MIRANDA, J. L. (Org.). Projeto cadastro de fontes de abastecimento por água subterrânea. Diagnóstico do município de Garanhuns, estado de Pernambuco. Recife: CPRM/PRODEEM, 2005.

MELO, F. P. de; MELO e SOUZA, R. Delimitação dos bairros da cidade de Garanhuns-PE em shapefiles. Garanhuns, 2015.

MENDONÇA, Francisco. Geografia e meio ambiente. 6 ed. São Paulo: Contexto, 2002.

NUCCI, J. C. Qualidade ambiental e adensamento urbano: um estudo de ecologia e planejamento da paisagem aplicado ao distrito de Santa Cecília (MSP). 2 ${ }^{a}$. ed. Curitiba: O Autor, 2008.

OLIVEIRA, A. C. A; MELO E SOUZA, R. Contribuições do método geossistêmico aos estudos integrados da paisagem. Revista GEOAMBIENTE, n.19, p. 157-175, jun.-dez. 2012. 
OLIVEIRA, C. H. Planejamento ambiental na cidade de São Carlos (SP) com ênfase em áreas públicas e áreas verdes: diagnóstico e propostas. 1996, 196f. Dissertação (Mestrado em Geografia) - Universidade Federal de São Carlos. São Carlos: UFSCar, 1996.

OLIVEIRA, L. A.; MASCARÓ, J. J. Análise da qualidade de vida urbana sob a ótica dos espaços públicos de lazer. Ambiente Construído, v. 7, n. 2, p. 59-69, abr.-jun. 2007.

PEDROSA, J. A. G; GAIA, M. C. M. Caracterização dos usos e funções de duas áreas verdes públicas urbanas no munícipio de Nova Lima, Minas Gerais. Acervo de Iniciação Científica, n.2, p. 1-24, 2013.

SANTANA, T. C. S; ELALI, G. A. A vitalidade em espaços livres urbanos: uma busca de elementos para a análise de praças em Natal-RN. Anais do $1^{\circ}$ Congresso Internacional de espaço público, p. 1-9. 2015.

SILVA FILHO, A. F.; GOMES, H. A; Osako L. S.; GUIMARÃES, I. P.; BRASIL, E. A.; LIMA, D. R.; COCENTINO, L.; VILLAVERDE, V. G. R.; VASCONCELOS, C. L.. Garanhuns-SC.24-X-B-VI, escala 1:100.000: nota explicativa. Pernambuco/Alagoas: UFPE /CPRM, 2007.

\author{
Ana Maria Severo Chaves \\ Mestre em Geografia pela Universidade pela Universidade federal de Sergipe e \\ Doutoranda em Geografia pela Universidade federal de Sergipe. Rua Major João \\ Teles, 750, CEP: 49100-000, bairro Rosa Elze, São Cristóvão-SE. \\ E-mail: anamschaves05@gmail.com \\ Rosemeri Melo e Souza \\ Professora do Programa de Pós-Graduação em Geografia e do Departamento de \\ Engenharia Ambiental da Universidade Federal de Sergipe. \\ Av. Adélia Franco, 3720- Edf. Nápoles, 703, CEP: 49040-020, bairro Inácio Barbosa \\ - Aracaju/SE. \\ E-mail: rome@ufs.br
}

Recebido para publicação em março de 2017

Aprovado para publicação em fevereiro de 2018 